\title{
Effect of homogenization of cream on composition, yield, and functionality of Cheddar cheese made from milk supplemented with ultrafiltered milk ${ }^{1}$
}

\author{
Bonney S. OOMmen, Vikram V. MistrY*, Manoj G. NAIR \\ Minnesota-South Dakota Dairy Foods Research Center, \\ Dairy Science Department, South Dakota State University, \\ Brookings, SD 57007, USA
}

\begin{abstract}
Cheddar cheeses were made from milks supplemented with ultrafiltered skim milk to 4.57 and $5.93 \%$ protein and from milks without supplementation to serve as controls (3.18\% protein). Milks were standardized (casein-to-fat ratio of 0.7 ) with unhomogenized cream or homogenized $(6.9 / 3.45 \mathrm{MPa}) \mathrm{cream}$. The six treatments were replicated five times. Rennet clotting time decreased with protein concentration and homogenization of cream increased it. $\mathrm{k}_{20}$, the time to reach an amplitude of $20 \mathrm{~mm}$ on formagraph after rennet clotting time, decreased with homogenization and concentration. $\mathrm{a}_{40}$, the amplitude on formagraph after $40 \mathrm{~min}$ of rennet addition, increased with protein and homogenization. Cheese moisture ranged from 37.29 to $39.37 \%$ and the proportion of fat in dry matter ranged from 52.9 to $53.7 \%$. Cheese yield adjusted to $37 \%$ moisture and $1.5 \%$ salt and adjusted yield per kg protein increased significantly in treatments with both protein concentration and homogenization. Fat recovered in cheese decreased with concentration in unhomogenized treatments while it increased in homogenized treatments. Protein recovery increased with protein concentration. A sensory panel did not detect any significant difference in flavor, flavor intensity, and body and texture with protein supplementation, but there was a significant increase in the body and texture scores in treatments with homogenization. Hardness of cheeses increased in treatments with concentration. Meltability of cheese increased with age in homogenized treatments. Free oil and free oil on fat basis decreased in treatments with homogenization and concentration. These two parameters also decreased with cheese age with a larger decrease for the homogenized treatments.
\end{abstract}

Cheddar cheese / homogenization / ultrafiltration

\footnotetext{
${ }^{1}$ Published with the approval of director of the South Dakota Agricultural Experiment Station as Publication Number 3139 of the Journal Series. This research was sponsored, in part, by the MinnesotaSouth Dakota Dairy Foods Research Center, Brookings, SD and Dairy Management, Inc., Rosemont, IL.

* Correspondence and reprints. vikram_mistry@sdstate.edu
} 


\section{INTRODUCTION}

Milk concentration prior to cheese manufacture has the advantages of increased yield and higher throughput [15]. Moreover, it can also be used to standardize cheese milk, so that uniformity in finished product composition and quality may be maintained [9]. Ultrafiltration is a selective low-pressure membrane concentration process which separates high molecular weight species (10 000 to $200000 \mathrm{~g} \cdot \mathrm{mol}^{-1}$ ) from a fluid stream. The mechanism of this process and its applications in the dairy industry have been well documented [18, 19, 24]. For Cheddar cheese making, milk concentrated by ultrafiltration up to 2 times does not require modifications in equipment $[3,11]$, but the cheese may have short body and mealy texture [14]. Kosikowski et al. [17] reported that high quality Cheddar cheese could be made from milk supplemented between 1.5 and 1.9 times. Significant reduction in yield due to high fat losses in whey were reported when cheese was made using traditional equipment from milk concentrated by ultrafiltration and having milk protein levels $>5 \%$ [8]. The fat loses can be attributed to the coarse protein network, segregation of fat from protein, and decrease in fat/protein interfacial area [7].

Fat losses during Cheddar cheese making may be lowered by using homogenized milk; however, homogenization of milk caused curd shattering and improper curd matting $[6,27]$, possibly because of the adverse effects of homogenization on milk proteins. These disadvantages of milk homogenization on cheese making were minimized by using homogenized cream in the manufacture of reduced fat Cheddar cheese $[21,22]$. This selective homogenization of fat improved the body and texture, increased cheese yield, and reduced free oil in reduced fat Cheddar cheese [21, 22]. This principle of cream homogenization was applied to full fat Cheddar cheese with similar results [25] and has also been reported to produce a "non-fat leaking" Cheddar cheese [26, 38].
In a previous study on selective homogenization of milk fat in the manufacture of Cheddar cheese [25] it was found that homogenization of cream improved the body and texture and functionality and also increased the fat and protein recovery in cheese, thus increasing cheese yield. It was concluded that first and second stage homogenization pressures of 6.9 and 3.5 $\mathrm{MPa}$ for $35 \%$ fat cream was optimum for the manufacture of Cheddar cheese.

The objective of the present investigation was to study the effects of homogenization of $35 \%$ fat cream at 6.9 and $3.5 \mathrm{MPa}$, respectively on the composition, yield, and functionality of Cheddar cheese made from milk supplemented with ultrafiltered milk up to a protein concentration of $5.93 \%$.

\section{MATERIALS AND METHODS}

\subsection{Ultrafiltration}

Raw whole milk $(1,950 \mathrm{~kg})$ was separated at $4{ }^{\circ} \mathrm{C}$ (De Laval Separator Co., New York, NY, USA) to $0.53 \%$ fat and then pasteurized at $73{ }^{\circ} \mathrm{C}$ for $15 \mathrm{~s}$, cooled to $4{ }^{\circ} \mathrm{C}$ and stored. This milk was warmed to $55^{\circ} \mathrm{C}$ and ultrafiltered using a spiral wound membrane of $5.6 \mathrm{~m}^{2}$ surface area (model 1/1; Koch Membrane Systems Inc., Wilmington, MA, USA) to a final five-fold volumetric concentration (approximately $16.15 \%$ protein). The ultrafiltered milk (retentate) was cooled to $16{ }^{\circ} \mathrm{C}$ and stored at $4{ }^{\circ} \mathrm{C}$ in $38 \mathrm{~L}$ stainless steel cans. Ultrafiltration was conducted in five batches $(330 \mathrm{~kg}$ of milk per batch). All retentates were warmed to $21^{\circ} \mathrm{C}$, pooled, transferred into $9 \mathrm{~kg}$ plastic containers and frozen at $-20{ }^{\circ} \mathrm{C}$ until used.

\subsection{Cheese milk standardization}

Raw whole milk at $4{ }^{\circ} \mathrm{C}$ was separated to $0.53 \%$ fat milk and approximately $40 \%$ fat cream. The cream was standardized to $35 \%$ fat using the separated milk and was 
split into two parts. One part was homogenized (P1) in a two stage Gaulin homogenizer (Manton Gaulin, Haskon Inc., St. Paul, $\mathrm{MN}, \mathrm{USA}$ ) at $55^{\circ} \mathrm{C}$ at first and second stage pressures of 6.9 and $3.5 \mathrm{MPa}$, respectively while the other part was pumped through the homogenizer with no pressure (P0). The creams were pasteurized immediately at $65.5^{\circ} \mathrm{C}$ for $30 \mathrm{~min}$ and cooled and stored at $4{ }^{\circ} \mathrm{C}$. The separated milk was pasteurized at $62.8^{\circ} \mathrm{C}$ for $30 \mathrm{~min}$, cooled and stored at $4{ }^{\circ} \mathrm{C}$ until used.

Cheddar cheeses were manufactured from milks with (C1 and $\mathrm{C} 2$ ) or without (C0) supplementation with ultrafiltered milk (16.15\% protein). Milks were standardized (casein-to-fat ratio of 0.7) with unhomogenized or homogenized cream. The six treatments included milks with $3.18 \%$ protein $(\mathrm{P} 0 \mathrm{C} 0, \mathrm{P} 1 \mathrm{C} 0), 4.57 \%$ protein $(\mathrm{P} 0 \mathrm{C} 1, \mathrm{P} 1 \mathrm{C} 1)$ and $5.93 \%$ protein $(\mathrm{P} 0 \mathrm{C} 2, \mathrm{P} 1 \mathrm{C} 2)$ and were replicated five times. The mixing of $0.53 \%$ fat milk, cream, and ultrafiltered milk for the standardization of cheese milks and subsequent cheese making were done in two $250 \mathrm{~kg}$ cheese vats (4 MX Model $65^{\circledR}$; Kusel Equipment Co., Watertown, WI, USA) prior to cheese making. The weight of cheese milk for $\mathrm{C} 0$ was $113.5 \mathrm{~kg}$ and for $\mathrm{C} 1$ and $\mathrm{C} 2,68 \mathrm{~kg}$.

\subsection{Cheese manufacture}

Two randomly selected treatments of cheese were made per day. Cheeses for one replicate, i.e., six vats of cheese, were made within three consecutive days. The temperature of cheese milk was raised to $32{ }^{\circ} \mathrm{C}$ and the following were added: $0.4 \mathrm{~mL}$ of calcium chloride/kg milk (Marschall Foods division, Rhône-Poulenc, Madison, WI, USA), $0.03 \mathrm{~mL}$ of annatto color $/ \mathrm{kg}$ milk (Marschall Foods division, Rhône-Poulenc, Madison, WI, USA), and direct vat set mesophilic starter culture (M58 or M61; Superstart Starter, Marschall Foods division, Rhône-Poulenc, Madison, WI, USA) at the rate of $8.26 \mathrm{~g} \cdot \mathrm{kg}^{-1}$ protein in milk in all the treatments except $\mathrm{P} 1 \mathrm{C} 0$ where it was added at $6.06 \mathrm{~g} \cdot \mathrm{kg}^{-1}$ protein. This lower rate of starter addition in $\mathrm{P} 1 \mathrm{C} 0$ was a measure to control the cheese moisture which tends to increase when homogenized cream is used [21] After $30 \mathrm{~min}$ of ripening, doublestrength rennet extract $\left(\right.$ Chymax ${ }^{\circledR}$, Pfzier Food Science, Dairy Ingredients Division, Pfzier Inc., Milwaukee, WI, USA) was added at the rate of $0.11 \mathrm{~mL} \cdot \mathrm{kg}^{-1}$ of milk. When the rennet curd was firm, it was cut using $0.65 \mathrm{~cm}$ wire knives and allowed to heal for $15 \mathrm{~min}$. The curds were cooked to $36{ }^{\circ} \mathrm{C}$ (P0C1, P0C2), $37{ }^{\circ} \mathrm{C}$ (P0C0, P1C1, $\mathrm{P} 1 \mathrm{C} 2)$ or $39{ }^{\circ} \mathrm{C}(\mathrm{P} 1 \mathrm{C} 0)$ in $30 \mathrm{~min}$. They were held at those temperatures and stirred for $60 \mathrm{~min}$ for $\mathrm{P} 1 \mathrm{C} 0,30 \mathrm{~min}$ for $\mathrm{P} 0 \mathrm{C} 0$, $\mathrm{P} 0 \mathrm{C} 1, \mathrm{P} 0 \mathrm{C} 2$ and $35 \mathrm{~min}$ for P1C1 and P1C2 before the whey was drained and collected. These differences in cook temperatures and holding times were measures taken to ensure similar cheese moisture in all treatments. During cheddaring, the curds were turned every $20 \mathrm{~min}$, milled at a $\mathrm{pH}$ of 5.2, salted at the rate of $2.75 \%$ milled curd and hooped in $9 \mathrm{~kg}$ rectangular hoops. They were pressed overnight at $276 \mathrm{kPa}$ (Kusel AFVSSpec., Kusel Equipment Co., Duncan, SC, USA), dehooped, weighed, packaged in Cryovac ${ }^{\circledR}$ bags (Cryovac Division, W.R. Crace and Co., Duncan, SC, USA), sealed under a vacuum (Multivac ${ }^{\circledR}$, Koch Inc., Kansas City, MO, USA) and ripened at $4-6{ }^{\circ} \mathrm{C}$ for 24 weeks. Whey expelled during pressing was collected in polyethylene bags, which were wrapped around each hoop.

\subsection{Sampling}

Cheese milks at $32{ }^{\circ} \mathrm{C}$ were sampled prior to the introduction of any additives and cooled immediately to $4{ }^{\circ} \mathrm{C}$. Whey drained after cooking, cheddaring, and salting was collected in $38 \mathrm{~L}$ cans, cooled and stored at $4{ }^{\circ} \mathrm{C}$. The next day, whey collected during pressing was pooled with the stored whey and warmed to $32{ }^{\circ} \mathrm{C}$ and sampled. The cheeses were sampled after 1, 4, 12, 
and 24 weeks by cutting a $1 \mathrm{~kg}$ block from the cheese block, shredding, and mixing and then drawing a representative sample for composition analysis.

\subsection{Analysis}

\subsubsection{Composition}

Fat in separated milk, cream, retentate, cheese milk, cheese, and whey was determined by the Mojonnier method [1, 2], total protein by the macro-Kjeldahl method [1] and ash by a muffle furnace at $550{ }^{\circ} \mathrm{C}[1$, 2]. Non-casein nitrogen in milk was determined with the Rowland method [28]. The total solids in cheese milk and whey were determined using the oven method [1, 2]. Cheese moisture was analyzed using an Ohaus MB200 moisture balance (Ohaus Corp., Florham Park, NJ, USA) [4]. Lactose content was calculated by difference. A sodium electrode with a Corning 150 analyzer (Corning Medical) [12] was employed for salt in cheese determination. Acid-soluble protein in cheese was determined by macro-Kjeldahl method [16].

\subsubsection{Rennet clotting properties}

The rennet clotting time (RCT), $\mathrm{k}_{20}$, and $\mathrm{a}_{40}$ of cheese milks were measured using a Formagraph (N Foss Electric, Hillerod, Denmark) [20]. One milliliter of double-strength rennet extract $\left(\mathrm{Chymax}^{\circledR}\right.$, Pfzier Food Science, Dairy Ingredients Division, Pfzier Inc., Milwaukee, WI, USA) was diluted to $100 \mathrm{~mL}$. From this, $110 \mu \mathrm{L}$ was mixed with $10 \mathrm{~mL}$ of milk at $35^{\circ} \mathrm{C}$. The RCT was measured as distance between the origin and the point where the baseline started to increase in width on the graph obtained on the recording chart. The time interval between RCT and an amplitude of $20 \mathrm{~mm}$ on the chart was measured as $\mathrm{k}_{20}$. The time required to reach $\mathrm{k}_{20}$ after rennet addition may be related to the time at which the curd is cut during cheese making [20]. The amplitude of the graph after 40 min of rennet addition is $\mathrm{a}_{40}$ and represents curd firmness after $40 \mathrm{~min}$.

\subsubsection{Functionality}

The texture profile analysis (TPA) of the cheeses at 1, 4, 12 and 24 weeks of age were done using a two-bite test to $75 \%$ [35]. A force distance curve was obtained using a Sintech texture instrument (model 2/D; MTS ${ }^{\circledR}$ Sintech Inc., Research Triangle Park, NC, USA) with a crosshead speed of $50 \mathrm{~mm} \cdot \mathrm{min}^{-1}$ and a $45.4 \mathrm{~kg}$ load cell, on $2 \mathrm{~cm} \times 2 \mathrm{~cm}$ cylindrical samples. Hardness and fracturability were determined using advanced software for materials testing version 2.1 (Test-works ${ }^{\mathrm{TM}}$ software; Research Triangle Park, NC, USA).

Meltability of cheeses at $1,4,12$, and 24 weeks was measured using the UW-Meltmeter [37]. It was expressed as the percentage change in height of cheese $(7 \mathrm{~mm}$ thickness and $30 \mathrm{~mm}$ diameter) after $10 \mathrm{~s}$ at a constant force of $0.36 \mathrm{~N}$ when heated to $60{ }^{\circ} \mathrm{C}$.

Free oil in cheeses at 1, 4, 12, and 24 weeks was measured using a modified Babcock test method [13] Free oil on fat basis was calculated as the ratio of percent free oil to fat percent in cheese and expressed as a percentage.

\subsubsection{Sensory evaluation}

An experienced panel of three judges evaluated the randomly coded cheeses for flavor, flavor intensity, and body and texture on an 11 point scale $(0=$ poor/low flavor intensity to $10=$ excellent/high flavor intensity) at 4, 12, and 24 weeks of age.

\subsection{Cheese yield}

Actual cheese yield was calculated as the weight of cheese obtained from $100 \mathrm{~kg}$ of milk after pressing. The adjusted yield was calculated at $37 \%$ moisture and $1.5 \%$ salt 
levels. Adjusted Yield $=$ Actual Yield $\times$ $(100-($ actual \% moisture + salt $)) /(100-$ (desired $\%$ moisture + salt $)$ ). Theoretical yield was calculated by the Van Slyke formula [34]. Van Slyke Yield $=[(0.93$ Fat $\%$ $+($ Casein $\%-0.1)) \times 1.09] /(100-$ Moisture $\%)$.

Fat and protein recoveries in cheese and whey were also determined. Component recovery $(\%)=(\%$ component in product $\times$ quantity of product $) /(\%$ component $\times$ quantity of milk) $\times 100$.

\subsection{Statistical analysis}

The design of the experiment was a $2 \times 3$ factorial in a randomized complete block with five replications of cheese making. The three levels of protein concentration $(\mathrm{C} 0$, $\mathrm{C} 1$, and $\mathrm{C} 2$ ) and homogenization with or without (P0 and P1) were the main effects. Composition was analyzed as a randomized complete block design. Functionality and sensory data were analyzed as repeated measures in a factorial design. SAS ${ }^{\circledR}[29]$ software was used to analyze the data using PROC ANOVA for composition and PROC MIXED for yield, functionality, and sensory. The least squares means were separated at $P=0.05$.

\section{RESULTS AND DISCUSSION}

\subsection{Composition of cheese milk}

The ultrafiltered milk represented 4.9 times concentration (protein basis). Approximately $86.8 \%$ of the fat and $5.9 \%$ of the protein in cheese milk was homogenized in the P1 treatments. Fat and protein contents of the cheese milks increased $(P<0.05)$ with concentration while they were the same among homogenized and unhomogenized treatments (Tab. I). The mean protein in $\mathrm{C} 0$, $\mathrm{C} 1$, and $\mathrm{C} 2$ were $3.18,4.57$, and $5.93 \%$ respectively, indicating a concentration of 1.43 times in $\mathrm{C} 1$ and 1.86 times in $\mathrm{C} 2$ relative to $\mathrm{C} 0$. The casein-to-fat ratios in cheese milks were maintained at $0.7 \pm 0.01$. The lactose content in milk calculated by difference was $4.81,4.61$, and $4.48 \%$ in $\mathrm{C} 0$, $\mathrm{C} 1$, and $\mathrm{C} 2$ respectively. These low levels of lactose in higher protein concentrations would not have been achieved if vacuum condensed milk or reverse osmosis retentate or dried milks were used for supplementation. The casein-to-protein ratio was $0.76,0.79$ and 0.80 for $\mathrm{C} 0, \mathrm{C} 1$, and $\mathrm{C} 2$ respectively. This increase is due to the loss of non-protein nitrogen by ultrafiltration.

\subsection{Composition of cheese and whey}

Fat in cheese varied between 32.30 to $33.92 \%$ but the fat in dry matter was not significantly different $(P>0.05)$ among treatments. Protein, moisture, and moisture in fat free substances of cheese ranged between 23.49 and $25.18 \%, 39.37$ and $36.2 \%$, and 54.8 and $58.2 \%$, respectively (Tab. I). Though an increase in moisture with homogenization may be expected [21] it was not evident here as changes in cheese making parameters such as cook temperature and holding time were made. As it is known that homogenization and ultrafiltration results in cheeses with varying composition, the cheese making parameters like rate of starter culture addition, cook temperature, holding time were altered within the treatments so that cheeses with similar composition were made. From an earlier study [25] it was found that there was an effect of homogenization pressure within the homogenized treatments on the different parameters studied even though the different cheese making parameters were not altered. So it can be assumed that the effects on parameters studied in this experiment were due to the treatments rather than the varied cheese making parameters.

Salt and salt in moisture phase of cheese in the homogenized treatments were higher $(P<0.05)$ than in the unhomogenized treatments. This is due to the reduced syneresis during and after salting in the homogenized 
Table I. Composition ${ }^{1}$ of cheese milk, Cheddar cheese, and whey.

\begin{tabular}{lcccccc}
\hline \multicolumn{5}{c}{ Treatments $^{2}$} \\
\cline { 2 - 7 } & P0C0 & P0C1 & P0C2 & P1C0 & P1C1 & P1C2 \\
\hline Cheese milk & & & & & \\
Fat, \% & $3.43^{\mathrm{c}}$ & $5.17^{\mathrm{b}}$ & $6.77^{\mathrm{a}}$ & $3.49^{\mathrm{c}}$ & $5.19^{\mathrm{b}}$ & $6.84^{\mathrm{a}}$ \\
Protein, \% & $3.18^{\mathrm{c}}$ & $4.56^{\mathrm{b}}$ & $5.91^{\mathrm{a}}$ & $3.19^{\mathrm{c}}$ & $4.58^{\mathrm{b}}$ & $5.95^{\mathrm{a}}$ \\
Casein, \% & $2.42^{\mathrm{d}}$ & $3.58^{\mathrm{c}}$ & $4.71^{\mathrm{b}}$ & $2.45^{\mathrm{d}}$ & $3.61^{\mathrm{c}}$ & $4.78^{\mathrm{a}}$ \\
Total Solids, \% & $12.08^{\mathrm{e}}$ & $15.14^{\mathrm{c}}$ & $18.04^{\mathrm{b}}$ & $12.19^{\mathrm{d}}$ & $15.22^{\mathrm{c}}$ & $18.16^{\mathrm{a}}$ \\
Cheddar cheese & & & & & & \\
Fat, \% & & & & & \\
Protein,\% & $32.48^{\mathrm{b}}$ & $33.50^{\mathrm{a}}$ & $33.92^{\mathrm{a}}$ & $32.30^{\mathrm{b}}$ & $32.64^{\mathrm{b}}$ & $33.56^{\mathrm{a}}$ \\
Moisture, \% & $24.19^{\mathrm{b}}$ & $24.45^{\mathrm{b}}$ & $25.18^{\mathrm{a}}$ & $23.49^{\mathrm{c}}$ & $23.57^{\mathrm{c}}$ & $24.00^{\mathrm{b}, \mathrm{c}}$ \\
Ash, \% & $39.03^{\mathrm{a}}$ & $37.56^{\mathrm{b}}$ & $36.20^{\mathrm{b}}$ & $39.37^{\mathrm{a}}$ & $38.72^{\mathrm{a}}$ & $37.29^{\mathrm{b}}$ \\
Salt, \% & $2.98^{\mathrm{c}}$ & $3.14^{\mathrm{b}}$ & $3.30^{\mathrm{a}, \mathrm{b}}$ & $3.25^{\mathrm{b}}$ & $3.28^{\mathrm{a}, \mathrm{b}}$ & $3.43^{\mathrm{a}}$ \\
SM ${ }^{3}, \%$ & $1.09^{\mathrm{b}}$ & $1.10^{\mathrm{b}}$ & $1.18^{\mathrm{b}}$ & $1.53^{\mathrm{a}}$ & $1.40^{\mathrm{a}}$ & $1.48^{\mathrm{a}}$ \\
FDM $^{4}, \%$ & $2.8^{\mathrm{d}}$ & $2.9^{\mathrm{c}, \mathrm{d}}$ & $3.3^{\mathrm{b}, \mathrm{c}}$ & $3.9^{\mathrm{a}}$ & $3.6^{\mathrm{ab}}$ & $4.0^{\mathrm{a}}$ \\
MFFS, \% & $52.9^{\mathrm{a}}$ & $53.7^{\mathrm{a}}$ & $53.2^{\mathrm{a}}$ & $53.3^{\mathrm{a}}$ & $53.3^{\mathrm{a}}$ & $53.5^{\mathrm{a}}$ \\
pH ${ }^{6}$ & $57.6^{\mathrm{a}}$ & $56.5^{\mathrm{b}, \mathrm{c}}$ & $54.8^{\mathrm{d}}$ & $58.2^{\mathrm{a}}$ & $57.5^{\mathrm{a}, \mathrm{b}}$ & $56.1^{\mathrm{c}}$ \\
Whey & $5.04^{\mathrm{c}}$ & $5.09^{\mathrm{b}, \mathrm{c}}$ & $5.17^{\mathrm{a}}$ & $5.12^{\mathrm{a}, \mathrm{b}}$ & $5.06^{\mathrm{b}, \mathrm{c}}$ & $5.14^{\mathrm{a}, \mathrm{b}}$ \\
Fat, \% & & & & & & \\
Protein, \% & & & & & & \\
Ash, \% & $0.222^{\mathrm{c}}$ & $0.360^{\mathrm{b}}$ & $0.565^{\mathrm{a}}$ & $0.167^{\mathrm{d}}$ & $0.225^{\mathrm{c}}$ & $0.342^{\mathrm{b}}$ \\
Total Solids, \% & $0.88^{\mathrm{d}}$ & $1.23^{\mathrm{b}}$ & $1.54^{\mathrm{a}}$ & $0.90^{\mathrm{d}}$ & $1.20^{\mathrm{c}}$ & $1.54^{\mathrm{a}}$ \\
\hline
\end{tabular}

a, b, c, d, e Means in rows with no common superscripts differ $(P<0.05)$

${ }^{1}$ Means of 5 replicate batches.

${ }^{2} \mathrm{P} 0=$ unhomogenized cream, $\mathrm{P} 1=$ homogenized cream, $\mathrm{C} 0=3.18 \%$ protein in milk, $\mathrm{C} 1=4.57 \%$ protein in milk, $\mathrm{C} 2=5.93 \%$ protein in milk.

${ }^{3}$ Salt in moisture phase of cheese.

${ }^{4}$ Fat in dry matter.

${ }^{5}$ Moisture in fat free substances.

${ }^{6} \mathrm{pH}$ after pressing at day 1 .

treatments. Salt content was not affected by ultrafiltration. Fat and protein percentages in whey increased $(P<0.05)$ with increase in protein concentration and fat was lower in the homogenized cream treatments (Tab. I).

\subsection{Rennet clotting properties}

The $\mathrm{P} \times \mathrm{C}$ interaction were not significant $(P>0.05)$ for RCT but it was significant $(P<0.05)$ for $\mathrm{k}_{20}$ and $\mathrm{a}_{40}$ (Tab. II). Therefore means of RCT were compared by averaging over $\mathrm{P}$ and $\mathrm{C}$ (Tab. III). The mean RCT and $\mathrm{k}_{20}$ averaged over $\mathrm{P} 0$ and P1 decreased $(P<0.05)$ with concentration from $27.1(\mathrm{C} 0)$ to $17.2 \mathrm{~min}(\mathrm{C} 2)$, and 30.85 (C0) to $4.35 \mathrm{~min}(\mathrm{C} 2)$, respectively. The $\mathrm{a}_{40}$ increased $(P<0.05)$ from $8.6(\mathrm{C} 0)$ to 61.15 $\mathrm{mm}(\mathrm{C} 2)$, i.e., curd firmness increased with concentration. Similar observations were reported by Green et al. [6] and Guinee et al. [8] for ultrafiltered milks and may be attributed to a decrease in the aqueous phase volume due to ultrafiltration which increases the number of effective collisions, increased secondary phase interactions due to an increase in calcium concentration, and an 
Table II. Analysis of variance for rennet clotting properties, yield, and fat and protein recovery.

\begin{tabular}{|c|c|c|c|}
\hline \multirow[b]{2}{*}{ Attribute } & \multicolumn{3}{|c|}{ F value for source of variation } \\
\hline & $\mathrm{P}^{1}$ & $\mathrm{C}^{2}$ & $\mathrm{P} \times \mathrm{C}$ \\
\hline $\mathrm{RCT}^{3}$ & $4.25^{*}$ & $176.24^{*}$ & $1.96^{\mathrm{NS}}$ \\
\hline $\mathrm{k}_{20}^{4}$ & $18.49 *$ & $932.83 *$ & $9.18^{*}$ \\
\hline$a_{40}^{20}$ & $33.84 *$ & $2002.30 *$ & $4.22 *$ \\
\hline Actual yield 6 & $110.38 *$ & $4819.60 *$ & $7.15^{*}$ \\
\hline Van Slyke yield $^{7}$ & $21.12 *$ & $3855.34 *$ & $1.29^{\mathrm{NS}}$ \\
\hline Adjusted yield ${ }^{8}$ & $144.08^{*}$ & $19683.99 *$ & $9.45^{*}$ \\
\hline Adjusted yield per $\mathrm{kg}$ fat & $25.44 *$ & $3.28^{\mathrm{NS}}$ & $1.23^{\mathrm{NS}}$ \\
\hline Adjusted yield per kg protein & $61.43^{*}$ & $60.23^{*}$ & $0.50^{\mathrm{NS}}$ \\
\hline Fat recovery in cheese ${ }^{9}$ & $127.30 *$ & $6.04 *$ & $4.14^{*}$ \\
\hline Fat recovery in whey ${ }^{10}$ & $423.26^{*}$ & $11.12 *$ & $11.55^{*}$ \\
\hline Total fat recovery ${ }^{11}$ & $2.63^{\mathrm{NS}}$ & $0.97^{\mathrm{NS}}$ & $1.81^{\mathrm{NS}}$ \\
\hline Protein recovery in cheese ${ }^{12}$ & $7.28 *$ & $38.15^{*}$ & $0.29^{\mathrm{NS}}$ \\
\hline Protein recovery in whey ${ }^{13}$ & $55.05^{*}$ & $482.67 *$ & $2.71^{\mathrm{NS}}$ \\
\hline Total protein recovery ${ }^{14}$ & $0.16^{\mathrm{NS}}$ & $9.60 *$ & $0.03^{\mathrm{NS}}$ \\
\hline
\end{tabular}

\footnotetext{
* Significant $(P<0.05)$.

NS Not significant $(P>0.05)$.

${ }^{1}$ There were two levels of $\mathrm{P}$ : without homogenization (P0) and with homogenization (P1).

${ }^{2}$ There were three protein concentration levels: $3.18 \%(\mathrm{C} 0), 4.57 \%(\mathrm{C} 1)$ and $5.93 \%(\mathrm{C} 2)$.

${ }^{3} \mathrm{RCT}=$ Rennet clotting time.

${ }^{4} \mathrm{k}_{20}=$ time taken for amplitude on formagraph to reach $20 \mathrm{~mm}$ after rennet clotting time.

${ }^{5} \mathrm{a}_{40}=$ amplitude on formagraph after 40 min of rennet addition.

${ }^{6}$ Yield of cheese not adjusted for salt and moisture.

${ }^{7}$ Theoretical yield based on Van Slyke formula.

${ }^{8}$ Yield adjusted to $37 \%$ moisture and $1.5 \%$ salt.

$9,10,12,13 \mathrm{~kg}$ of component recovered per $\mathrm{kg}$ component in milk.

${ }^{13}, 14$ Sum of the recoveries of component in cheese and whey.
}

increase in the protein as a percentage of total solids. Homogenization increased $(P<0.05) \mathrm{RCT}$ and $\mathrm{a}_{40}$ from 20.6 to $21.5 \mathrm{~min}$ and 36.1 to $40.1 \mathrm{~mm}$ respectively. This increase in $\mathrm{a}_{40}$ may be explained by the participation of homogenized fat globules in the formation of gel structure due to adsorbed casein on its surface [30] which increases the solid material entrapped in the gel rather than trapped within the voids of the gel. The increase in $\mathrm{a}_{40}$ with concentration was greater with treatments which included homogenized cream (Tab. III). Though $\mathrm{k}_{20}$ decreased $(P<0.05)$ from 15.3 to 12.9 min with homogenization, homogenization had no effect on $\mathrm{k}_{20}$ for $\mathrm{C} 1$ and $\mathrm{C} 2$ (Tab. III).

\subsection{Cheese making characteristics}

Curds from all homogenized treatments were more elastic than the unhomogenized ones at cheddaring. No curd shattering or improper matting was observed during cheese making. Greater quantities of fines were observed in $\mathrm{P} 0 \mathrm{C} 2$ than in $\mathrm{P} 1 \mathrm{C} 2$.

\subsection{Cheese yield}

The analysis of variance for yield is shown in Table II. Where $\mathrm{P} \times \mathrm{C}$ is significant, treatment means are compared and where they are not, either $\mathrm{P}$ means averaged over $\mathrm{C}$ or $\mathrm{C}$ means averaged over $\mathrm{P}$ are com- 
Table III. Rennet clotting properties ${ }^{1}$ of cheese milk.

\begin{tabular}{|c|c|c|c|c|c|c|}
\hline & \multicolumn{6}{|c|}{ Treatments $^{2}$} \\
\hline & $\mathrm{POC} 0$ & P0C1 & P0C2 & $\mathrm{P} 1 \mathrm{C} 0$ & $\mathrm{P} 1 \mathrm{C} 1$ & $\mathrm{P} 1 \mathrm{C} 2$ \\
\hline $\mathrm{RCT}^{3}, \min$ & 26.00 & 18.85 & 16.90 & 28.20 & 18.90 & 17.50 \\
\hline $\mathrm{k}_{20}{ }^{4}, \mathrm{~mm}$ & $33.7^{\mathrm{a}}$ & $7.45^{c}$ & $4.75^{d}$ & $28.0^{\mathrm{b}}$ & $6.85^{c}$ & $3.95^{\mathrm{d}}$ \\
\hline $\mathrm{a}_{40}, \mathrm{~mm}$ & $8.00^{\mathrm{e}}$ & $42.00^{d}$ & $58.30^{\mathrm{b}}$ & $9.20^{\mathrm{e}}$ & $47.20^{c}$ & $64.00^{\mathrm{a}}$ \\
\hline
\end{tabular}

a, b, c, d, e Means in rows with no common superscripts differ $(P<0.05)$.

${ }^{1}$ Means of 5 replicate batches.

${ }^{2} \mathrm{P} 0=$ unhomogenized cream, $\mathrm{P} 1=$ homogenized cream, $\mathrm{C} 0=3.18 \%$ protein in milk, $\mathrm{C} 1=4.57 \%$ protein in milk, $\mathrm{C} 2=5.93 \%$ protein in milk.

${ }^{3} \mathrm{RCT}=$ Rennet clotting time.

${ }_{5}^{4} \mathrm{k}_{20}=$ time taken for amplitude on formagraph to reach $20 \mathrm{~mm}$ after rennet clotting time.

$5 \mathrm{a}_{40}=$ amplitude on formagraph after $40 \mathrm{~min}$ of rennet addition.

Table IV. Yield ${ }^{1}$ and component recovery ${ }^{1}$ of Cheddar cheese made with homogenized cream and ultrafiltered milk.

\begin{tabular}{|c|c|c|c|c|c|c|}
\hline & \multicolumn{6}{|c|}{ Treatments $^{2}$} \\
\hline & $\mathrm{P} 0 \mathrm{C} 0$ & $\mathrm{P} 0 \mathrm{C} 1$ & $\mathrm{P} 0 \mathrm{C} 2$ & $\mathrm{P} 1 \mathrm{C} 0$ & $\mathrm{P} 1 \mathrm{C} 1$ & $\mathrm{P} 1 \mathrm{C} 2$ \\
\hline \multicolumn{7}{|l|}{ Yield } \\
\hline Actual yield ${ }^{3}, \%$ & $10.03^{\mathrm{f}}$ & $14.61^{\mathrm{d}}$ & $18.56^{\mathrm{b}}$ & $10.46^{\mathrm{e}}$ & $15.39^{c}$ & $19.68^{\mathrm{a}}$ \\
\hline Van Slyke yield ${ }^{4}, \%$ & 9.85 & 14.46 & 18.64 & 10.07 & 14.84 & 19.18 \\
\hline Adjusted yield ${ }^{5}, \%$ & $9.76^{\mathrm{f}}$ & $14.57^{\mathrm{d}}$ & $18.90^{\mathrm{b}}$ & $10.05^{\mathrm{e}}$ & $14.98^{\mathrm{c}}$ & $19.59^{\mathrm{a}}$ \\
\hline Adjusted yield per $\mathrm{kg}$ fat & 2.85 & 2.82 & 2.79 & 2.88 & 2.89 & 2.87 \\
\hline Adjusted yield per kg protein & 3.07 & 3.20 & 3.19 & 3.15 & 3.27 & 3.29 \\
\hline \multicolumn{7}{|l|}{ Recovery } \\
\hline Fat recovery in cheese ${ }^{6}, \%$ & $94.40^{\mathrm{b}}$ & $94.73^{\mathrm{b}}$ & $92.99^{\mathrm{c}}$ & $96.81^{\mathrm{a}}$ & $96.75^{\mathrm{a}}$ & $96.61^{\mathrm{a}}$ \\
\hline Fat recovery in whey ${ }^{7}, \%$ & $5.95^{\mathrm{b}}$ & $6.03^{b}$ & $6.92^{\mathrm{a}}$ & $4.39^{c}$ & $3.72^{\mathrm{d}}$ & $4.09^{\mathrm{c}, \mathrm{d}}$ \\
\hline Total fat recovery ${ }^{8}, \%$ & 100.35 & 100.76 & 99.91 & 101.2 & 100.47 & 100.70 \\
\hline Protein recovery in cheese ${ }^{9}, \%$ & 76.26 & 78.39 & 78.98 & 77.09 & 79.19 & 79.39 \\
\hline Protein recovery in whey ${ }^{10}, \%$ & 25.91 & 23.44 & 21.57 & 24.97 & 22.41 & 21.12 \\
\hline Total protein recovery ${ }^{11}, \%$ & 102.17 & 101.83 & 100.55 & 102.06 & 101.6 & 100.51 \\
\hline
\end{tabular}

a, b, c, d, e Means in rows with no common superscripts differ $(P<0.05)$.

${ }^{1}$ Means of 5 replicate batches.

${ }^{2} \mathrm{P} 0=$ unhomogenized cream, $\mathrm{P} 1=$ homogenized cream, $\mathrm{C} 0=3.18 \%$ protein in milk, $\mathrm{C} 1=4.57 \%$ protein in milk, $\mathrm{C} 2=5.93 \%$ protein in milk.

${ }^{3}$ Yield of cheese not adjusted for salt and moisture.

${ }^{4}$ Theoretical yield based on Van Slyke formula.

${ }^{5}$ Yield adjusted to $37 \%$ moisture and $1.5 \%$ salt.

$6,7,9,10 \mathrm{~kg}$ of component recovered per kg component in milk.

8,11 Sum of the recoveries of component in cheese and whey.

pared (Tab. IV). The actual and Van Slyke yield increased $(P<0.05)$ in treatments with concentration and homogenization
(Tab. IV). The actual yield was higher compared to Van Slyke yield for the homogenized treatments, indicating higher fat and 
protein recovery with homogenization. The increase of adjusted yield with concentration was higher when homogenized cream was used. It increased by $93.6 \%$ from P0C0 to P0C2. When homogenized cream was used, the corresponding increase was $94.9 \%$. This increase in yield due to homogenization is in agreement with the observation of others $[21,25]$. Adjusted yield per $\mathrm{kg}$ fat in milk was significantly higher $(P<0.05)$ in $\mathrm{P} 1$ compared to $\mathrm{P} 0$, an increase of $2.01 \%$, thus showing higher fat recovery in cheese with homogenization. Adjusted yield per kg protein in milk increased $(P<0.05)$ with concentration due to the increased whey protein recovery in cheese. It also increased $(P<0.05)$ with homogenization by $2.7 \%$ because homogenization increased casein recovery.

Mistry and Kosikowski [23] reported an increase in yield when milk was supplemented to 1.88 times the total protein. Guinee et al. [9] observed that losses of fat and protein in whey were not influenced by milk protein level when cheese was made from milks with protein levels ranging from 3 to $4.6 \%$.

Fat recovery in cheese decreased $(P<0.05)$ in treatments with concentration for $\mathrm{P} 0$ while it was same $(P>0.05)$ for P1 (Tab. IV). The decrease in fat recovery may be due to lower degree of aggregation of the casein micelles when the curd was cut [6], coarse protein network and reduced fat/protein interfacial area [7]. The coarse protein network would have led to the tearing of the coagulum while cutting thus decreasing the fat recovery in cheese. Guinee et al. [8] reported that fat losses in whey were greater for milk containing more than $5 \%$ protein. Homogenization increases the fat/protein interfacial area, which aids in a stable complex formation between fat and protein [5] Though casein is predominant, some whey proteins are also present in the protein part of the complex [30, 36]. These casein particles adsorbed to the fat globule surfaces help the globules to aggregate with caseins and form an integral part of the gel structure. Thus, fat lost due to increased concentration can be recovered back by employing homogenization of the fat.

Protein recovery in cheese increase $(P<0.05)$ in treatments with concentration and homogenization (Tab. IV). Cheese retains some whey proteins when made from ultrafiltered milk [15]. The stable fat-protein complex formed due to homogenization of cream improves casein recovery as the complex forms a part of the cheese structure.

\section{6. $\mathrm{pH}$}

$\mathrm{pH}$ of cheeses varied significantly $(P<0.05)$ with cheese age (Fig. 1). Also $\mathrm{pH}$ increased with concentration for all ages except for $\mathrm{P} 1 \mathrm{C} 0$ which had a higher $\mathrm{pH}$ due to lesser quantity of starter inoculation during cheese making. The increase in $\mathrm{pH}$ with milk protein concentration might be due to the higher buffering capacity of the milk proteins in higher protein milks [14].

\subsection{Acid-soluble protein}

Acid-soluble protein content in cheeses increased $(P<0.05)$ with age due to proteolysis but decreased $(P<0.05)$ with concentration, indicating lower proteolysis in higher concentration (Fig. 2). The slower rate of proteolysis in cheeses made from ultrafiltered milks has been attributed to lower rennet to casein ratios, inhibition of plasmins by $\beta$-lactoglobulin retained, and the resistance of undenatured whey proteins to degradation $[6,10]$. Homogenization had no effect on acid-soluble protein (Tab. V).

\subsection{Functionality}

The TPA-hardness and TPA-fracturability of cheese increased $(P<0.05)$ in treatments with increased protein concentration in cheese milk (Tab. V, Fig. 3). Lower moisture content in cheese, lower levels of 


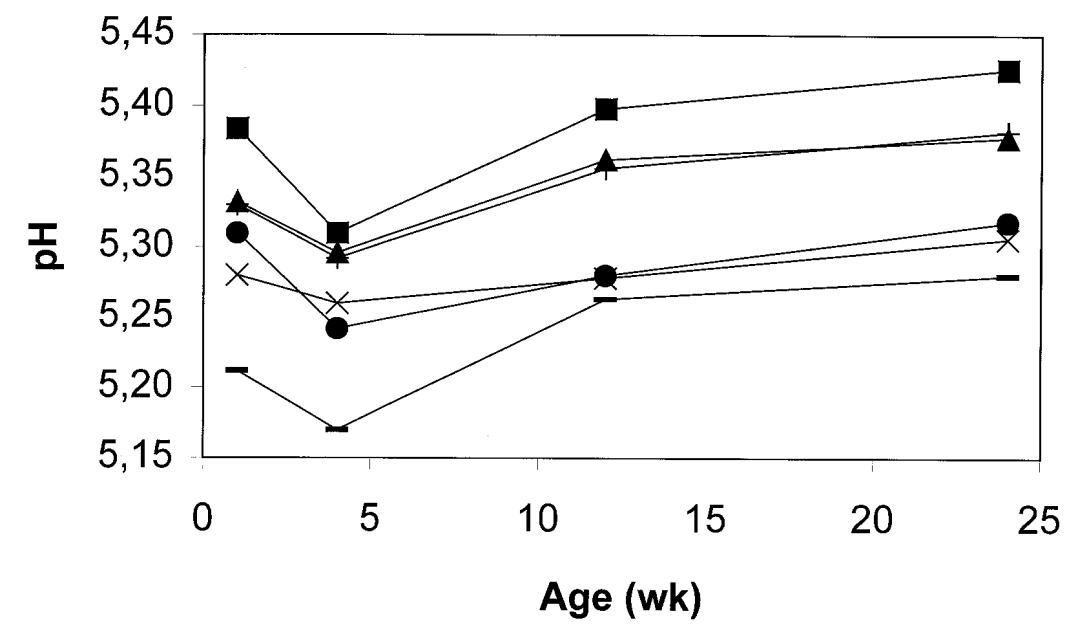

Figure 1. $\mathrm{pH}$ of cheese as a function of age. (-) P0C0; $(\bullet) \mathrm{P} 0 \mathrm{C} 1 ;(\mathbf{\Delta}) \mathrm{P} 0 \mathrm{C} 2 ;(\boldsymbol{\square}) \mathrm{P} 1 \mathrm{C} 0 ;(\times) \mathrm{P} 1 \mathrm{C} 1$; (+) $\mathrm{P} 1 \mathrm{C} 2$. $\mathrm{P} 0=$ unhomogenized cream, $\mathrm{P} 1=$ homogenized cream, $\mathrm{C} 0=3.18 \%$ protein in milk, $\mathrm{C} 1=4.57 \%$ protein in milk, $\mathrm{C} 2=5.93 \%$ protein in milk.

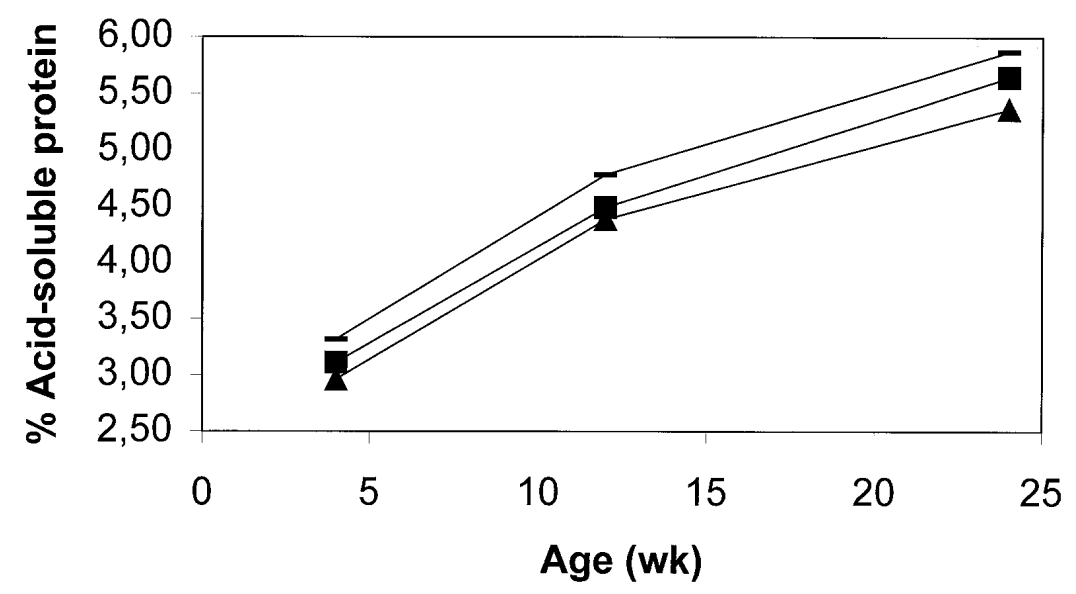

Figure 2. Effect of protein concentration of cheese milk on acid-soluble protein content with age of cheese. $\mathrm{C} 0(-)=3.18 \%$ protein in milk, $\mathrm{C} 1(\boldsymbol{\square})=4.57 \%$ protein in milk, $\mathrm{C} 2(\boldsymbol{\Delta})=5.93 \%$ protein in milk. Means averaged across $P$.

proteolysis, coarser and stronger protein networks, and reduced ability of fat and protein phase to move in relation to each other [7] tend to increase hardness and fracturability. There was a decrease in hardness $(P=0.0517)$ and fracturability $(P<0.05)$ with cheese age due to the breakdown of the protein network during proteolysis.
Treatments with homogenized cream produced cheeses which were resistant to fracture, but as concentration increased, the cheeses tended to fracture. As the cheeses aged, they produced typical compression curves as in the control cheese ( $\mathrm{POC} 0$ ) which clearly showed the yield point of fracturability. 


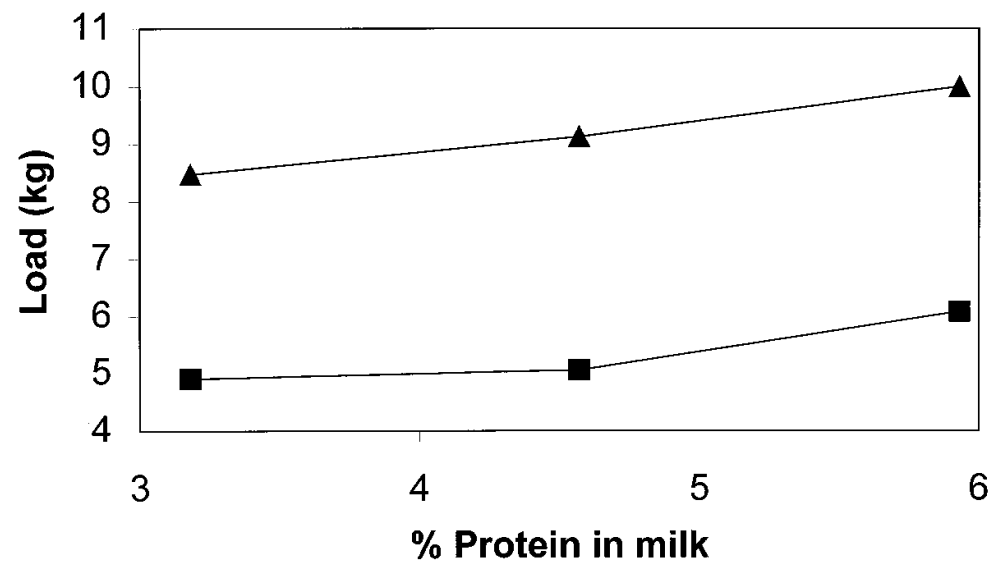

Figure 3. Hardness $(\boldsymbol{\Delta})$ and fracturability $(\boldsymbol{\square})$ of cheese as a function of protein concentration in cheese milk. Means averaged across $\mathrm{P}$ and all ages.

Meltability of cheese increased $(P<0.05)$ with age up to 4 weeks which may be attributed to the breakdown of the casein matrix, release of calcium, and increased hydration that occurs in cheese with proteolysis [18]. Homogenization increased $(P<0.05)$ meltability with aging (Tab. V and Fig. 4). Meltability was lower for homogenized treatments at 1 week but it became significantly higher at 12 weeks of age. The decrease in meltability with milk homogenization [33] was reported for Mozzarella cheese because of adsorption of casein on the fat droplets, which prevents the fat from spreading. The reversal of melt characteristics could not be observed in Mozzarella as it is not aged for longer periods. Meltability of cheese decreased with concentration at 1 and 4 weeks of cheese age for both homogenized and unhomogenized treatments (data not shown). Though the meltability continued to decrease with concentration at 12 and 24 weeks of age for the homogenized treatments, the trend reversed for the unhomogenized treatments. In spite of these interactions, the meltability of P1C0 was not different $(P>0.05)$ from $\mathrm{P} 0 \mathrm{C} 0$.
Sood and Kosikowski [31] suggested that the lowering in meltability in cheeses made from ultrafiltered milks is due to the entrapment of free moisture by the denatured whey proteins. Because of reduced syneresis in homogenized treatments, there is more moisture entrapped in the curd which may be responsible for lowering of meltability with homogenization when the cheese is young. As the cheese ages, the break down of casein and the release of the homogenized fat globules entrapped in the casein matrix due to proteolysis would probably increase the ability of casein micelles to slip around each other and may increase meltability of homogenized treatments.

Free oil and free oil on basis fat decreased $(P<0.05)$ by 10.4 and $9.4 \%$, respectively with homogenization (Tabs. V and VI). Wilson and Johnson [38] and Nichols [26] reported decrease in fat leakage in Cheddar cheese by homogenizing cream, while Peters [27] and Tunick [32] reported the same trend with homogenized milk. Free oil is an indication of the degree of emulsification of fat in cheese [22, 27, 32]. Homogenization decreases the fat globule size and there by increases the surface area of the globule [26] 
Table V. Analysis of variance for functional, textural, and sensory characteristics of Cheddar cheese.

\begin{tabular}{lccccccc}
\hline & \multicolumn{7}{c}{ F value for source of variation } \\
\cline { 2 - 8 } Attribute & $\mathrm{P}^{1}$ & $\mathrm{C}^{2}$ & $\mathrm{P} \times \mathrm{C}$ & Age $^{3}$ & $\mathrm{P} \times$ Age & $\mathrm{C} \times$ Age P $\times \mathrm{C} \times$ Age \\
\hline $\mathrm{PH}$ & $4.21^{\mathrm{NS}}$ & $1.98^{\mathrm{NS}}$ & $4.98^{*}$ & $26.40^{*}$ & $0.03^{\mathrm{NS}}$ & $1.52^{\mathrm{NS}}$ & $0.30^{\mathrm{NS}}$ \\
Acid-soluble protein & $4.14^{\mathrm{NS}}$ & $13.66^{*}$ & $0.02^{\mathrm{NS}}$ & $1635.37^{*}$ & $0.51^{\mathrm{NS}}$ & $1.13^{\mathrm{NS}}$ & $0.55^{\mathrm{NS}}$ \\
Hardness & $1.41^{\mathrm{NS}}$ & $5.18^{*}$ & $0.66^{\mathrm{NS}}$ & $2.72^{\mathrm{NS}}$ & $0.65^{\mathrm{NS}}$ & $0.65^{\mathrm{NS}}$ & $0.37^{\mathrm{NS}}$ \\
Fracturability & $0.13^{\mathrm{NS}}$ & $5.74^{*}$ & $1.13^{\mathrm{NS}}$ & $9.81^{*}$ & $0.03^{\mathrm{NS}}$ & $0.57^{\mathrm{NS}}$ & $0.92^{\mathrm{NS}}$ \\
Meltability & $0.34^{\mathrm{NS}}$ & $0.90^{\mathrm{NS}}$ & $4.29^{*}$ & $53.69^{*}$ & $4.51^{*}$ & $2.11^{\mathrm{NS}}$ & $0.39^{\mathrm{NS}}$ \\
Free Oil & $23.50^{*}$ & $4.18^{*}$ & $0.53^{\mathrm{NS}}$ & $41.76^{*}$ & $3.61^{*}$ & $0.62^{\mathrm{NS}}$ & $0.24^{\mathrm{NS}}$ \\
FOFB & $20.97^{*}$ & $10.97^{*}$ & $0.069^{\mathrm{NS}}$ & $43.53^{*}$ & $3.90^{*}$ & $0.56^{\mathrm{NS}}$ & $0.25^{\mathrm{NS}}$ \\
Flavor & $19.66^{*}$ & $1.96^{\mathrm{NS}}$ & $2.45^{\mathrm{NS}}$ & $15.99^{*}$ & $1.16^{\mathrm{NS}}$ & $0.94^{\mathrm{NS}}$ & $0.68^{\mathrm{NS}}$ \\
Flavor intensity & $0.00^{\mathrm{NS}}$ & $0.10^{\mathrm{NS}}$ & $0.18^{\mathrm{NS}}$ & $33.10^{*}$ & $0.36^{\mathrm{NS}}$ & $0.29^{\mathrm{NS}}$ & $0.06^{\mathrm{NS}}$ \\
Body and texture & $73.52^{*}$ & $2.14^{\mathrm{NS}}$ & $1.12^{\mathrm{NS}}$ & $30.42^{*}$ & $1.36^{\mathrm{NS}}$ & $2.04^{\mathrm{NS}}$ & $1.09^{\mathrm{NS}}$ \\
\hline
\end{tabular}

* Significant $(P<0.05)$.

NS Not significant $(P>0.05)$.

${ }^{1}$ There were two levels of $\mathrm{P}$ : without homogenization $(\mathrm{P} 0)$ and with homogenization $(\mathrm{P} 1)$.

${ }^{2}$ There were three protein concentration levels: $3.18(\mathrm{C} 0), 4.57(\mathrm{C} 1)$ and $5.93 \%(\mathrm{C} 2)$.

${ }^{3}$ Cheeses were analyzed at $1,4,12$ and 24 weeks.

${ }^{4} \mathrm{FOFB}=$ of free oil on fat basis.

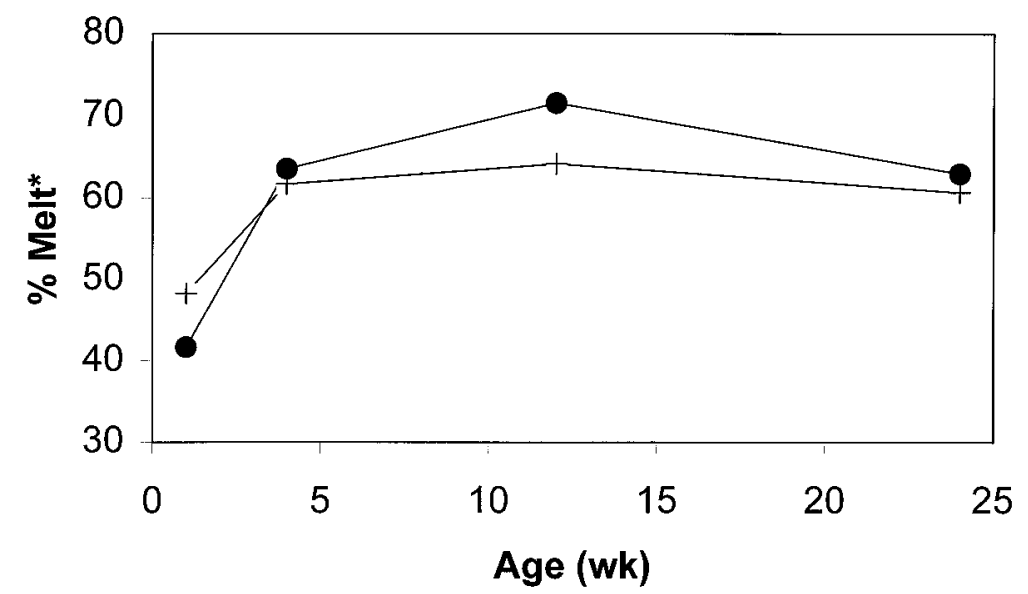

Figure 4. Meltability of cheese as a function of age averaged across all protein concentrations. * Change in height of cheese at $60^{\circ} \mathrm{C}$ in $10 \mathrm{~s}$. (+) Unhomogenized treatments; (๑) Homogenized treatments.

which necessitates additional surface-active material. Adsorption of casein on the fat globules [30] whose surface area is increased by homogenization increases the emulsification of fat.

Free oil and free oil on fat basis decreased $(P<0.05)$ by 7.3 and $11.3 \%$, respectively with ultrafiltration. The close protein network in cheeses made from higher protein milk tend to entrap the fat and thus reduce the free oil in cheese. A combination of both homogenization and protein concentration can reduce free oil on fat basis to a large extent (Tab. VI). 
Table VI. Free oil and free oil on fat basis ${ }^{1}$.

\begin{tabular}{lll}
\hline & \multicolumn{2}{c}{ Attribute } \\
\cline { 2 - 3 } & Free oil & FOFB $^{2}$ \\
\hline Homogenization $^{3}$ & & \\
P0 & $12.77^{\mathrm{A}}$ & $38.46^{\mathrm{A}}$ \\
P1 & $11.44^{\mathrm{B}}$ & $34.83^{\mathrm{B}}$ \\
Concentration & & \\
C0 & & \\
C1 & $12.66^{\mathrm{A}}$ & $39.17^{\mathrm{A}}$ \\
C2 & $11.92^{\mathrm{B}}$ & $36.00^{\mathrm{B}}$ \\
Age (weeks) & $11.73^{\mathrm{B}}$ & $34.76^{\mathrm{B}}$ \\
1 & & \\
4 & $14.26^{\mathrm{A}}$ & $43.15^{\mathrm{A}}$ \\
12 & $12.31^{\mathrm{B}}$ & $37.29^{\mathrm{B}}$ \\
24 & $11.74^{\mathrm{B}}$ & $35.54^{\mathrm{B}}$ \\
\hline
\end{tabular}

A, B, C Means in columns within the same parameter with no common superscripts differ $(P<0.05)$.

${ }^{1}$ Means of 5 replicate batches.

${ }^{2}$ Free oil on fat basis.

${ }^{3} \mathrm{P} 0=$ unhomogenized cream, $\mathrm{P} 1=$ homogenized cream.

${ }^{4} \mathrm{C} 0=3.18 \%$ protein in milk, $\mathrm{C} 1=4.57 \%$ protein in milk, $\mathrm{C} 2=5.93 \%$ protein in milk.

A decrease $(P<0.05)$ in free oil as well as free oil on fat basis was observed when the cheeses aged (Tabs. V and VI). This decrease was more prominent for the homogenized treatments as seen from a significant $(P<$ $0.05) \mathrm{P} \times$ Age interaction (Tab. V). This decrease in free oil was not expected with age because the cheese which undergoes proteolysis with age, would release the fat entrapped in the casein matrix. In another experiment Nair et al. [25] reported an increase in free oil with age in Cheddar cheese for both homogenized and unhomogenized treatments. As free oil is an indicator of the extent of fat emulsification, it can be assumed that there was a controlled release of some components with age due to proteolysis. These components probably were good emulsifiers. Further exploration may be needed to study the mechanism involved in this phenomenon.

\subsection{Sensory characteristics}

Flavor, flavor intensity, and body and texture were influenced by cheese age and flavor, and body and texture were influenced by homogenization (Tabs. VI and VII). Increase in flavor scores with homogenization may be due to the higher percent salt in moisture phase of cheese and salt content in homogenized treatments. Flavor scores decreased $(P<0.05)$ with aging. Panelists reported bitterness in aged cheese, which may be the reason for lower scores. Flavor intensity increased $(P<0.05)$ with age as expected. Body and texture scores increased $(P<0.05)$ with homogenization. The homogenized treatments had a longer body compared to the unhomogenized treatments. The body and texture scores of P1C2 were greater $(P<0.05)$ than those of the control (P0C0) at all ages. The cheeses did not develop any rancid flavor related to the susceptibility of homogenized fat to increased lipolysis. Immediate pasteurization after homogenizing the cream would have inactivated the lipase enzyme.

\section{CONCLUSION}

It is well known that ultrafiltration of milk prior to cheese making helps increase the yield of cheese. This study has demonstrated that the yield can be further increased by using homogenized cream in addition to ultrafiltration, thus improving cheese making efficiency. Furthermore, homogenized cream increased meltability of cheese with age and improved the meltability of cheeses made from ultrafiltered milk. Free oil and free oil on fat basis decreased with homogenization, concentration, and age. These characteristics would open more avenues for the use of these processes of homogenization of cream and ultrafiltration in cheese manufacture if it can be demonstrated that the improved functionality can be carried over to those foods where these cheeses are used as ingredients. Homogenization of 
Table VII. Effect of homogenization and cheese age on sensory characteristics ${ }^{1}$.

\begin{tabular}{cccc}
\hline & \multicolumn{3}{c}{ Attribute } \\
\cline { 2 - 4 } & Flavor & $\begin{array}{c}\text { Flavor } \\
\text { intensity }\end{array}$ & Body and \\
& & & \\
Homogenture \\
P0 & $6.89^{\mathrm{B}}$ & 5.79 & $6.49^{\mathrm{B}}$ \\
P1 & $7.26^{\mathrm{A}}$ & 5.79 & $7.32^{\mathrm{A}}$ \\
Age (weeks) & & & \\
4 & $7.39^{\mathrm{A}}$ & $5.11^{\mathrm{C}}$ & $6.37^{\mathrm{B}}$ \\
12 & $6.94^{\mathrm{B}}$ & $5.86^{\mathrm{B}}$ & $7.13^{\mathrm{A}}$ \\
24 & $6.88^{\mathrm{B}}$ & $6.39^{\mathrm{A}}$ & $7.21^{\mathrm{A}}$ \\
\hline
\end{tabular}

A, B, C Means in columns within the same parameter with no common superscripts differ $(P<0.05)$.

${ }^{1}$ Means of 5 replicate batches. Eleven point hedonic scale was used in which $0=$ poor/low flavor intensity to $10=$ excellent/high flavor intensity.

${ }^{2} \mathrm{P} 0=$ unhomogenized cream, $\mathrm{P} 1=$ homogenized cream.

cream and ultrafiltration may be used in combination to tailor make cheeses meeting customer specifications for functional attributes. The homogenized treatments were characterized by their higher body and texture scores. Milk supplemented up to $5.93 \%$ protein with ultrafiltration may be used to make good quality Cheddar cheese with high yield and solids recovery, and improved functionality by using homogenized cream as a fat source.

\section{ACKNOWLEDGMENTS}

The authors thank K. Muthukumarappan and J. Stout of the Agricultural and Bio-Systems Engineering Department at South Dakota State University, for use of the melt-meter and texture analyzer and P. Evenson for help with statistical analysis.

\section{REFERENCES}

[1] Association of Official Analytical Chemistry, Official Methods of Analysis, 16th ed., AOAC Int., Arlington, VA, 1995.
[2] Atherton H.V., Newlander J.A., Chemistry and Testing of Dairy Products, 4th ed., AVI Publ. Co., Inc., Westport, CT, 1977.

[3] Chapman H.R., Bines V.E., Glover F.A., Skudder P.J., Use of milk concentrated by ultrafiltration for making hard cheese, soft cheese and yogurt, J. Soc. Dairy Technol. 27 (1974) 151-155.

[4] Crosser A.E., Mistry V.V., Use of a moisture balance to determine moisture in cheese, J. Dairy Sci. 74 (1991) (Suppl. 1) 126 (abstr.).

[5] Fox K.K., Holsinger V.H., Caha J., Pallansch M.J., Formation of a fat protein complex in milk by homogenization, J. Dairy Sci. 43 (1960) 1396-1406.

[6] Green M.L., Glover F.A., Scurlock E.M.W., Marshall R.J., Hatfield D.S., Effect of use of milk concentrated by ultrafiltration on the manufacture and ripening of Cheddar cheese, J. Dairy Res. 48 (1981) 333-341.

[7] Green M.L., Turvey A., Hobbs D.G., Development of structure and texture in Cheddar Cheese, J. Dairy Res. 48 (1981) 343-355.

[8] Guinee T.P., Pudja P.D., Mulholland E.O., Effect of milk protein standardization, by ultrafiltration, on the manufacture, composition and maturation of Cheddar cheese, J. Dairy Res. 61 (1994) 117-131.

[9] Guinee T.P., O'Callaghan D.J., Mulholland E.O., Harrington D., Milk protein standardization by ultrafiltration for Cheddar cheese manufacture, J. Dairy Res. 63 (1996) 281-293.

[10] Harper J., Iyer M., Knighton D., Lelievre J., Effects of whey proteins on the proteolysis of Cheddar cheese slurries (A model for the maturation of cheeses made from ultrafiltered milk), J. Dairy Sci. 72 (1989) 333-341.

[11] Kealey K.S., Kosikowski F.V., Cheddar cheese from ultrafiltered whole milk retentates in industrial cheese making, J. Dairy Sci. 68 (1985) 3148-3154.

[12] Kindstedt P.S., Kosikowski F.V., Measurement of sodium chloride in cheese by a simple ion electrode method, J. Dairy Sci. 67 (1984) 879-883.

[13] Kindstedt P.S., Rippe J.K., Rapid quantitative test for free oil (oiling off) in melted Mozzarella cheese, J. Dairy Sci. 73 (1990) 867-873.

[14] Kosikowski F.V., Characteristics of cheese and cheese making using water milk retentates of ultrafiltration, J. Dairy Sci. 62 (1979) (Suppl. 1) 59 (abstr.).

[15] Kosikowski F.V., Mistry V.V., Cheese and Fermented Milk Foods, Vol. 1, Origins and Principles, F.V. Kosikowski, L.L.C., Westport, CT, 1997.

[16] Kosikowski F.V., Mistry V.V., Cheese and Fermented Milk Foods, Vol. 2, Procedures and Analysis, F.V. Kosikowski, L.L.C., Westport, CT, 1997, pp. 223-224. 
[17] Kosikowski F.V., Masters A.R., Mistry V.V., Cheddar cheese from retentate supplemented whole milk, J. Dairy Sci. 68 (1985) 548-554.

[18] Lawrence R.C., The use of ultrafiltration technology in cheesemaking, IDF Document B 136, Int. Dairy Fed., Brussels, Belgium, 1987.

[19] Maubois J.-L., Mocquot G., Application of membrane ultrafiltration to preparation of various types of cheese, J. Dairy Sci. 58 (1975) 1001-1007.

[20] McMahon D.J., Brown R.J., Evaluation of formagraph for comparing rennet solutions, J. Dairy Sci. 65 (1982) 1639-1642.

[21] Metzger L.E., Mistry V.V., A new approach using homogenization of cream in the manufacture of reduced fat Cheddar cheese, 1. Manufacture, composition, and yield, J. Dairy Sci. 77 (1994) 3506-3515.

[22] Metzger L.E., Mistry V.V., A new approach using homogenization of cream in the manufacture of reduced fat Cheddar cheese, 2. Microstructure, fat globule distribution, and free oil, J. Dairy Sci. 78 (1994) 1883-1895.

[23] Mistry V.V., Kosikowski F.V., Yield and quality of Cheddar cheese from high somatic cell milk supplemented with retentate to varying concentrations or directly ultrafiltered, J. Dairy Sci. 71 (1988) 2333-2341.

[24] Mistry V.V., Maubois J.L., Application of ultrafiltration in cheesemaking, in: Fox P.F. (Ed.), Cheese: Chemistry, Physics, and Microbiology, 2nd ed., Vol 1, Chapman and Hall, New York, NY, 1993, pp. 493-522.

[25] Nair M.G., Mistry V.V., Oommen B.S., Yield and functionality of Cheddar cheese as influenced by homogenization of cream, J. Dairy Sci. 82 (1999) (Suppl. 1) 18 (abstr.).

[26] Nichols L.E., The manufacture of a non-fat leaking Cheddar cheese from reconstituted milk, Queensland J. Agric. Sci. 5 (1947) 39-60.
[27] Peters I.I., Cheddar cheese made from pasteurized milk homogenized at various pressures, J. Dairy Sci. 39 (1956) 1083-1088.

[28] Rowland S., Determination of nitrogen distribution in milk, J. Dairy Res. 9 (1938) 42-46.

[29] SAS $^{\circledR}$ User's Guide: Statistics, version 6.0, SAS Inst., Inc., Cary, NC, 1990.

[30] Sharma S.K., Dalgleish D.G., Interactions between milk serum proteins and synthetic fat globule membranes during heating of homogenized whole milk, J. Agric. Food Chem. 41 (1993) 1407-1412.

[31] Sood V.K., Kosikowski F.V., Process Cheddar cheese from plain and enzyme treated retentates, J. Dairy Sci. 62 (1979) 1713-1718.

[32] Tunick M.H., Effects of homogenization and proteolysis on free oil in Mozzarella cheese, J. Dairy Sci. 77 (1994) 2487-2493.

[33] Tunik M.H., Malin E.L., Smith P.W., Shieh J.J., Sullivan B.C., Mackey K.L., Holsinger V.H., Proteolysis and rheology of low fat and full fat Mozzarella cheeses prepared from homogenized milk, J. Dairy Sci. 76 (1993) 3621-3628.

[34] van Slyke L.L., Price W.V., Cheese, Orange Judd Publ. Co. New York, NY, 1941, pp. 71.

[35] van Vliet T., Terminology to be used in cheese rheology, in: Rheological and Fracture Properties of Cheese, IDF Bulletin No. 268, Int. Dairy Fed., Brussels, Belgium, pp. 5-15.

[36] Walstra P., Physical chemistry of milk fat globules, in: Fox P.F. (Ed.), Developments in Dairy Chemistry-2, Applied Science Publishers, London, 1983, pp. 119-158.

[37] Wang Y.-C., Muthukumarappan K., Ak M.M., Gunasekaran S., A device for evaluating melt/flow characteristics of cheeses, J. Texture Stud. 29 (1998) 43-55.

[38] Wilson H.L., Johnson W.T., Process to prevent the oiling off or leakage of butterfat in cheese, US Pat. No. 2, 127, 453, 1938 